\title{
脳血管疾患急性期患者における上肢機能の予後予測に関する研究 一研究デザインと初回調査時における対象者の特性及び急性期症状一
}

\author{
曽根 稔雅 $*^{1}$, 中谷 直樹 $*^{2}$, 五百川和明 $*^{1}$, 長谷川敬一 $*^{3}$, \\ 塚田 徹 $*^{3}$, 金田麻利子 $*^{3}$, 濱口 豊太 $*^{4}$ \\ *1 東北福祉大学健康科学部リハビリテーション学科作業療法学専攻 \\ *2 $^{2}$ 東北大学東北メディカル・メガバンク機構予防医学・疫学部門 \\ *3竹田綜合病院リハビリテーション科 \\ *4 埼玉県立大学保健医療福祉学部作業療法学科
}

\author{
Prediction of Upper Limb Recovery in the Acute Phase \\ of Cerebrovascular Disease \\ —Study Design and Socio-demographic Profiles, Medical Profiles, \\ and Acute Symptoms of Participants at Baseline- \\ Toshimasa SONE*1, Naoki NAKAYA*2, Kazuaki IOKAWA*1, Keiichi HASEGAWA*3, \\ Tetsu TSUKADA*3, Mariko KANEDA*3 and Toyohiro HAMAGUCHI*4 \\ ${ }^{*}$ Course of Occupational Therapy, Department of Rehabilitation, Faculty of Health Science, Tohoku Fukushi University \\ *2Department of Preventive Medicine and Epidemiology, Tohoku Medical Megabank Organization, Tohoku University \\ *3 Department of Rehabilitation, Takeda General Hospital \\ ${ }^{*}$ Department of Occupational Therapy, School of Health and Social Services, Saitama Prefectural University
}

\begin{abstract}
Objectives: In this study, we aim to predict the recovery of upper limb function in patients in the acute phase of cerebrovascular disease. Here, we describe the study design and patients' characteristics at baseline.

Methods: Subjects were admitted to Takeda General Hospital with cerebrovascular disease, and were prescribed to undergo rehabilitation. The assessment was conducted between June 2010 and March 2011. The baseline survey assessed the following factors: socio-demographic profiles (age, sex, number of family members, key person, occupation, and activities in daily life), medical profiles (types of cerebrovascular disease, location of brain damage, and history of diseases), and acute symptoms (Japan Coma Scale score, the Barre arm sign, the Brunnstrom recovery stage, tendon reflex, sensation, pain, ataxia, range of motion, muscle tone, grip strength, agnosia, apraxia, aphasia, dysarthria, the Hasegawa Dementia Scale-Revised score, and the Barthel index).

Results: A total of 357 patients with cerebrovascular disease were analyzed on the basis of diagnosis [cerebral infarction (CI; 77.6\%), cerebral hemorrhage (CH; 20.2\%), subarachnoid hemorrhage (SAH; $\mathbf{2 . 2 \%}$ )]. There was a significant difference in the average age between the types of cerebrovascular disease. In acute symptoms, sensation, grip strength, cognitive function, and activities of daily living were statistically significantly different between the types of cerebrovascular disease.

Conclusions: In this report, we described the study design and characteristics of patients with cerebrovascular disease at baseline. In the future, this study could be used for predicting the recovery of upper limb function in these patients.
\end{abstract}

Key words: cerebrovascular disease（脳血管疾患）, upper limb function（上肢機能）, prognostic prediction（予 後予測), study design（研究デザイン）, acute symptoms（急性期症状） 


\section{緒言}

脳血管疾患発症後, 急性期の段階で機能予後を予測す ることができれば，リハビリテーションが必要とされる 期間が明確となる。先行研究では, 脳血管疾患患者の上 肢機能回復に関連する要因として, 年齢, 性別に加え, 発症時の上肢機能, 感覚, 筋緊張, 認知機能, 日常生活 活動（ADL）が挙げられている(1-3)。これらの要因を 網羅して短期的な上肢機能の予後を予測することができ れば，リハビリテーションの適切な目標設定が可能とな る。さらに, 病院から在宅及び施設等への円滑な移行が 可能となることで，在院期間の短縮につながると考光ら れる。そこで, 我々は脳血管疾患患者を対象に, 先行研 究で上肢機能の予後との関連が報告されている要因を基 に上肢機能の予後を予測することを目指している。本研 究は, 上肢機能の予後を予測するデータセットの構築に あたり, 研究デザインと対象者の特性及び急性期症状に ついて報告する。

脳血管疾患に打沙対象者の特性や急性期症状は上肢 機能の予後に大きな影響を及湆すことから（1-3），急性 期の段階で特性や症状を正確汁握することは重要であ る。日本国内に抢浽血管疾患の罹患率はいくつかの 先行研究で報告され $(4,5)$, 病型別の比率は脳梗塞が 6 , 脳出血が 2 , くも膜下出血が 1 で, 脳梗塞が大部分を占 めることが明らかにされている(5)。乙かし, 脳血管疾 患の病型別に対象者の特性や急性期症状を調查した研究 は少なく, 心身機能やADL に抢正性期症状の詳細 を調查した研究は十分に行わ和ていない $(6,7)$ 。

本研究は脳血管疾患患者に打汀る上肢機能の予後を予 測するため, ここでは研究デザインと初回調査時に和け る対象者の特性及び急性期症状について, 脳梗塞, 脳出 血，くも膜下出血の病型別飞報告する。

\section{方法}

\section{1. 対象者}

対象者は, 竹田綜合病院に急性発症した脳血管疾患で 入院し, リハビリテーションが処方された 20 歳以上の 者全員とした。初回調查期間は 2010 年 6 月 1 日〜 2011 年 5 月 31 日の 1 年間であり, 対象者は随時登録された。

竹田綜合病院は, 897 床の病床数を有し, 地域医療支 援病院，地域リハビリテーション広域支援センターの認 定を受けている。福島県会津地域のリハビリテーション 中核施設として，医療機関や福祉施設・保健所・市町村

受付 2014 年 6 月 5 日, 受理 2014 年 8 月 12 日

Reprint requests to: Toshimasa SONE

Course of Occupational Therapy, Department of Rehabilitation, Faculty of Health Science, Tohoku Fukushi University, 1-8-1 Kunimi, Aoba-ku, Sendai, Miyagi 981-8522, Japan

TEL: +81(22)728-6069

E-mail: sone-t@umin.ac.jp
等との連携をはかり，高齢者や障害者の地域での自立し た生活を支援している。

\section{2. 初回調査項目}

初回調查は，各対象者を担当する理学療法士，作業療 法士が聞き取り及び急性期症状の評価を行った。調査時 期は脳血管疾患の発症から 1 週間以内とした。

対象者の特性として, 年齢, 性別, 同居者数, キーパー ソン (配偶者，娘，息子，嫁，孫，いない，その他）, 職業歴（現在及び退職前）(会社員, 公務員, 農林水産業, 工業，商業，主婦，その他），病前の過ごし方（自宅外 の仕事 [役割]，家の仕事 [役割]，趣味，主にテレビ, その他, 特になし), 利き手 (右, 左) について調査した。 医学的情報は, 病型 (脳梗塞, 脳出血, く子膜下出血), 損傷部位（前頭葉，大脳皮質，内包，基底核，視床，脳 幹, 小脑), 麻疩側 (右, 左), 疾患既往歷 (脳血管疾患, 高血圧，心筋梗塞，腎疾患，肝疾患，糖尿病，胃・十二 指腸潰瘍，結核・肋膜炎，関節炎，骨粗鬆症，がん，高 脂血症，肺炎，気管支喘息，難聴，白内障，その他）を 調查した。急性期症状は，意識障害 (Japan coma scale $[\mathrm{JCS}])(1,2,3,10,20,30,100,200,300)(8)$, Barre arm sign（あり，なし), Brunnstrom recovery stage （BRS）上肢・手指（I， II， III， IV，V， VI）（9），腱 反射, 感覚, 痛及, 運動失調, 関節可動域, 筋緊張, 握 力，失認（あり，なし），失行（あり，なし，失語（あ り,なし), 構音障害 (あり,なし), 認知機能 (改訂長 谷川式簡易知能評価スケール [Hasegawa Dementia ScaleRevised; HDS-R $]$ ) (10), ADL (Barthel Index [BI $]$ ) (11) を調查した。

急性期症状に抢ける評価の詳細を以下に示す。腱反射 は, 上腕二頭筋飞沏いて克進, 正常, 減弱, 消失のいず れかを評価した。感覚は, 手掌部に扔いて脱失, 鈍麻, 正 常のいずれかを評価した。痛及は，上肢，手指における 痛みのあり，なしを評価した。運動失調は，上肢におけ る運動失調のあり,なしを評価した。関節可動域は，上 肢，手指に打ける制限のあり，なしを評価した。筋緊張 は, Modified Ashworth Scale を用いて，大胸筋の緊張を 段階的に評価した $(0,1,1+, 2,3,4)(12)$ 。認知機能は, 認知症のスクリーニングテストである HDS-Rを用い, 30 点満点で評価した (10)。ADL は BI を用い, ADL10 項目の実行状況を 100 点満点で評価した（11）。

\section{3. アウトカム調査項目}

脳血管疾患発症から 3 週後に Manual Function Test (MFT)，実用手・準実用手の評価を行った。MFTは， 脳血管疾患患者の麻瘦側上肢について, 神経学的回復時 期に抢忷る上肢運動機能の経時的変化を測定・記録する ために開発されたものである (13)。8 種類のテストで構 成さ氺，上肢・手指の基本動作及び巧緻動作の遂行能力 そついて 32 点満点で評価した。実用手の評価は, 利き 手では書字，箸による食事が努力しなくてもできる手， 
非利き手では汁茶碗を努力しないで持てる手とした （14）。また，準実用手はテストをすれば実用手の動作を できるが，スピードや巧緻性に欠け，日常生活では非麻 痺手を使っている手として評価した（14）。

\section{4. 統計解析}

初回調査時に打ける対象者の特性及び急性期症状は, 連続変数は年齢を一元配置分散分析, 握力を KruskalWallis 検定，カテゴリ変数は $\chi^{2}$ 検定を用いて脳梗塞群, 脳出血群, くも膜下出血群に预ける群間の差を比較した。 統計解析は SPSS Statistics 19.0 (SPSS Inc, Chicago, IL, USA）を使用した。すべての解析は両側検定で行い, $\mathrm{p}<0.05$ を統計学的に有意差ありとした。

\section{5. 倫理的配慮}

研究対象者には, 本研究で用いる評価項目は通常のリ ハビリテーション評価活用されるものであり, 本研究 のためだけに評価される項目ではないこと，対象となる ことを拒否する場合でも，不利益とならないことを説明 した。また, 研究の意義・目的, 研究方法, 本研究に打 利益・不利益, 個人情報の保護, 調査成果の公表, 対象となることの拒否, 研究責任者・連絡先についての 情報をリハビリテーション室内に揭示した。

な拉, 本研究課題は東北福祉大学倫理審查委員会 (RS100391), 竹田綜合病院倫理審査委員会（第 21-06 号） で承認されている。

\section{結果}

調査期間中に脳血管疾患で入院し，リハビリテーショ ンが処方された者は 418 人であった。これらの者から，
同意が得られなかった者 7 人，他の疾患の治療が優先さ 孔た者 40 人，両側飞麻痺があった者 1 人，日本語での コミュニケーションが困難であった者 1 人, 初回調査を 1 週間以内に実施できなかった者 11 人, 病型が不明だっ た者 1 人を除外し，最終的な解析対象者は 357 人（男性 190 人，女性 167 人） $(85.4 \%)$ であった（図 1)。初回調 查は発症から平均 1.5 日（標準偏差; 1.3 ) 飞行われていた。

表 1 は対象者の特性及び急性期症状について病型別に 示している。対象者の病型別の構成は，脳梗塞が 277 人 $(77.6 \%)$, 脳出血 72 人 $(20.2 \%)$, <子膜下出血 8 人 $(2.2 \%)$ であった。平均年齢は脳梗塞群で 76.1 歳, 脳出血群で 70.7 歳, くも膜下出血群で 71.1 歳であり, 3 群間におけ る有意差が認められた $(\mathrm{F}=6.47, \mathrm{p}<0.01)$ 。損傷部位 では，大脳皮質，視床，脳翰において，疾患既往歴では， 胃・十二指腸潰瘍，骨粗鬆症に执いて 3 群間での有意差 が認められた（大脳皮質： $\chi^{2}=20.39, p<0.01$, 視床： $\chi^{2}=49.55, \mathrm{p}<0.01$, 脳幹: $\chi^{2}=6.86, \mathrm{p}=0.03$, 胃 -十二 指腸潰瘍 : $\chi^{2}=6.44, p=0.04$, 骨粗鬆症 : $\chi^{2}=6.79, p=$ $0.03)$ 。疾患既往歴に打いて, 脳血管疾患では, くも膜 下出血群で既往者はいなかったが，脳梗塞群では $31.4 \%$, 脳出血群では $25.0 \%$ の既往者が認められた。高 血圧はいずれの群に抢いても約 5 割の対象者で既往が認 められた。

急性期症状では, 感覚, 握力, 認知機能, ADL 飞打 いて 3 群間での有意差が認められた（感覚: $\chi^{2}=17.63$, $\mathrm{p}<0.01$, 握力麻痺側: $\mathrm{H}=15.74, \mathrm{p}<0.01$, 握力非麻痺側: $\mathrm{H}=14.19, \mathrm{p}<0.01$, HDS-R $: \chi^{2}=7.31, \mathrm{p}=0.03, \mathrm{BI}: \chi^{2}$ $=18.51, \mathrm{p}<0.01$ )。脳梗塞群の対象者は, 約 9 割の者が 刺激なしに覚醒しており，BRS 上肢，手指でVIの者が 約 4 割，感覚が正常の者が約 6 割，握力の平均は麻疩側 で $10.0 \mathrm{~kg}$, 非麻痺側で $12.8 \mathrm{~kg}$ であった。脳出血群は,

2010年6月 1 日〜2011年5月 31 日までに脳血管疾患で入院し, リハビリテーションが処方された20歳以上の者全員

418 人

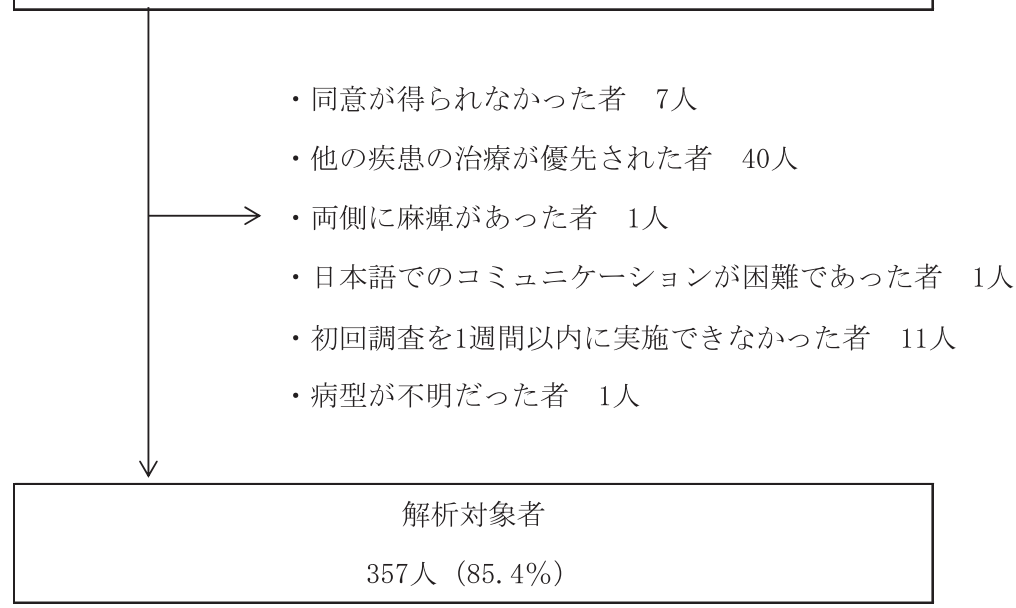

図 1 対象者の流れ図 
日衛誌 (Jpn. J. Hyg.) 第 70 巻 第 1 号 2015 年 1 月

表 1 初回調査時における病型別の対象者の特性及び急性期症状

\begin{tabular}{|c|c|c|c|c|}
\hline \multirow{2}{*}{ 変数 } & \multicolumn{3}{|c|}{ 病型 } & \multirow{2}{*}{$\mathrm{p}$ 値 } \\
\hline & 脳梗塞 & 脳出血 & くも膜下出血 & \\
\hline 対象者数 & 277 & 72 & 8 & \\
\hline \multicolumn{5}{|l|}{ 性別 $(\%)^{\mathrm{b}}$} \\
\hline 女性 & 47.3 & 41.7 & 75.0 & 0.19 \\
\hline \multicolumn{5}{|l|}{ 同居者数（\%)b } \\
\hline 1 人 & 16.5 & 5.8 & 12.5 & 0.25 \\
\hline 2 人 & 28.1 & 33.3 & 25.0 & \\
\hline 3 人以上 & 55.4 & 60.9 & 62.5 & \\
\hline \multicolumn{5}{|l|}{ キーパーソン $(\%)^{\mathrm{b}}$} \\
\hline 配偶者 & 30.7 & 40.0 & 37.5 & 0.12 \\
\hline 娘 & 18.2 & 12.9 & 25.0 & \\
\hline 息子 & 31.4 & 25.7 & 25.0 & \\
\hline 嫁 & 4.0 & 8.6 & 0.0 & \\
\hline 孫 & 0.7 & 1.4 & 0.0 & \\
\hline いない & 1.1 & 0.0 & 12.5 & \\
\hline その他 & 13.9 & 11.4 & 0.0 & \\
\hline \multicolumn{5}{|l|}{ 職業歴 $(\%)^{\mathrm{b}}$} \\
\hline 会社員 & 25.8 & 27.9 & 37.5 & 0.55 \\
\hline 公務員 & 3.1 & 7.4 & 0.0 & \\
\hline 農林水産業 & 25.8 & 23.5 & 37.5 & \\
\hline 工業 & 10.8 & 17.6 & 0.0 & \\
\hline 商業 & 12.3 & 5.9 & 12.5 & \\
\hline 主婦 & 8.5 & 8.8 & 0.0 & \\
\hline その他 & 13.8 & 8.8 & 12.5 & \\
\hline \multicolumn{5}{|l|}{ 病前の過ごし方 $(\%)^{\mathrm{b}}$} \\
\hline 自宅外の仕事 & 21.0 & 21.9 & 37.5 & 0.75 \\
\hline 家の仕事 & 32.8 & 34.4 & 37.5 & \\
\hline 趣味 & 10.7 & 7.8 & 12.5 & \\
\hline 主にテレビ & 14.1 & 21.9 & 0.0 & \\
\hline その他 & 3.8 & 1.6 & 0.0 & \\
\hline 特になし & 17.6 & 12.5 & 12.5 & \\
\hline \multicolumn{5}{|l|}{ 利き手 $(\%)^{\mathrm{b}}$} \\
\hline 右手 & 96.3 & 97.1 & 100.0 & 0.82 \\
\hline \multicolumn{5}{|l|}{ 損傷部位 $(\%)^{\mathrm{b}}$} \\
\hline 前頭葉 & 15.3 & 6.9 & 0.0 & 0.10 \\
\hline 大脳皮質 & 39.1 & 16.7 & 85.7 & $<0.01$ \\
\hline 内包 & 14.6 & 8.3 & 0.0 & 0.22 \\
\hline 基底核 & 19.3 & 25.0 & 0.0 & 0.23 \\
\hline 視床 & 7.3 & 38.9 & 0.0 & $<0.01$ \\
\hline 脳幹 & 18.2 & 6.9 & 0.0 & 0.03 \\
\hline 小脳 & 10.6 & 9.7 & 14.3 & 0.93 \\
\hline \multicolumn{5}{|l|}{ 麻痺側 $(\%)^{\mathrm{b}}$} \\
\hline 右 & 48.2 & 50.0 & 87.5 & 0.09 \\
\hline \multicolumn{5}{|l|}{ 疾患既往歴 $(\%)^{b}$} \\
\hline 脳血管疾患 & 31.4 & 25.0 & 0.0 & 0.10 \\
\hline 高血压 & 50.2 & 52.8 & 50.0 & 0.93 \\
\hline 心笳梗塞 & 5.8 & 2.8 & 12.5 & 0.40 \\
\hline 腎疾患 & 5.1 & 8.3 & 0.0 & 0.44 \\
\hline 肝疾患 & 2.5 & 5.6 & 0.0 & 0.37 \\
\hline 糖尿病 & 22.4 & 22.2 & 12.5 & 0.80 \\
\hline 胃・十二指腸潰瘍 & 7.6 & 0.0 & 0.0 & 0.04 \\
\hline 関節炎 & 4.3 & 2.8 & 12.5 & 0.42 \\
\hline 骨粗鬆症 & 1.1 & 2.8 & 12.5 & 0.03 \\
\hline がん & 11.6 & 15.3 & 25.0 & 0.39 \\
\hline 高脂血症 & 9.0 & 12.5 & 0.0 & 0.44 \\
\hline \multicolumn{5}{|l|}{ Japan Coma Scale $(\%)^{\mathrm{b}}$} \\
\hline 1 桁 & 89.5 & 80.6 & 75.0 & 0.08 \\
\hline 2 桁 & 7.2 & 16.7 & 25.0 & \\
\hline 3 桁 & 3.2 & 2.8 & 0.0 & \\
\hline
\end{tabular}


日衛誌 (Jpn. J. Hyg.) 第 70 巻 第 1 号 2015 年 1 月

表 1 （続き）

\begin{tabular}{|c|c|c|c|c|}
\hline \multirow{2}{*}{ 変数 } & \multicolumn{3}{|c|}{ 病型 } & \multirow{2}{*}{$\mathrm{p}$ 值 } \\
\hline & 脳梗塞 & 脳出血 & くも膜下出血 & \\
\hline 対象者数 & 277 & 72 & 8 & \\
\hline \multicolumn{5}{|l|}{ Barre arm sign $(\%)^{b}$} \\
\hline あり & 65.0 & 69.4 & 50.0 & 0.50 \\
\hline \multicolumn{5}{|c|}{ Brunnstrom Recovery Stage 上肢 $(\%)^{\mathrm{b}}$} \\
\hline I & 6.5 & 9.7 & 0.0 & 0.09 \\
\hline II & 11.6 & 25.0 & 25.0 & \\
\hline III & 6.2 & 11.1 & 12.5 & \\
\hline IV & 9.4 & 9.7 & 12.5 & \\
\hline $\mathrm{V}$ & 27.5 & 16.7 & 25.0 & \\
\hline VI & 38.8 & 27.8 & 25.0 & \\
\hline \multicolumn{5}{|c|}{ Brunnstrom Recovery Stage 手指 $(\%)^{\mathrm{b}}$} \\
\hline I & 9.0 & 12.5 & 0.0 & 0.15 \\
\hline II & 11.9 & 22.2 & 25.0 & \\
\hline III & 4.0 & 9.7 & 0.0 & \\
\hline IV & 9.0 & 6.9 & 12.5 & \\
\hline V & 27.4 & 19.4 & 37.5 & \\
\hline VI & 38.6 & 29.2 & 25.0 & \\
\hline \multicolumn{5}{|l|}{ 腱反射 $(\%)^{\mathrm{b}}$} \\
\hline 六進 & 19.6 & 22.5 & 12.5 & 0.40 \\
\hline 正常 & 69.9 & 59.2 & 87.5 & \\
\hline 減弱 & 9.1 & 16.9 & 0.0 & \\
\hline 消失 & 1.4 & 1.4 & 0.0 & \\
\hline \multicolumn{5}{|l|}{ 感覚 $(\%)^{b}$} \\
\hline 脱失 & 1.1 & 7.0 & 0.0 & $<0.01$ \\
\hline 鈍麻 & 37.3 & 53.5 & 37.5 & \\
\hline 正常 & 61.6 & 39.4 & 62.5 & \\
\hline \multicolumn{5}{|l|}{ 痛み $(\%)^{\mathrm{b}}$} \\
\hline あり & 9.8 & 13.9 & 0.0 & 0.37 \\
\hline \multicolumn{5}{|l|}{ 運動失調 $(\%)^{\mathrm{b}}$} \\
\hline あり & 12.3 & 15.3 & 0.0 & 0.44 \\
\hline \multicolumn{5}{|l|}{ 関節可動域 $(\%)^{b}$} \\
\hline 制限あり & 6.5 & 11.1 & 0.0 & 0.29 \\
\hline \multicolumn{5}{|c|}{ 筋緊張（Modified Ashworth Scale） $(\%)^{\mathrm{b}}$} \\
\hline 0 & 79.0 & 75.0 & 75.0 & 0.27 \\
\hline 1 & 16.3 & 13.9 & 25.0 & \\
\hline $1+\sim 4$ & 4.7 & 11.1 & 0.0 & \\
\hline \multicolumn{5}{|l|}{ 握力, $\mathrm{kg}$ (平均土標準偏差) ${ }^{\mathrm{c}}$} \\
\hline 麻痺側 & $10.0 \pm 11.4$ & $6.6 \pm 10.4$ & $0.0 \pm 0.0$ & $<0.01$ \\
\hline 非麻痺側 & $12.8 \pm 12.5$ & $10.3 \pm 12.4$ & $0.0 \pm 0.0$ & $<0.01$ \\
\hline \multicolumn{5}{|l|}{ 失認 $(\%)^{\mathrm{b}}$} \\
\hline あり & 6.9 & 9.9 & 0.0 & 0.50 \\
\hline \multicolumn{5}{|l|}{ 失行 $(\%)^{\mathrm{b}}$} \\
\hline あり & 2.5 & 1.4 & 0.0 & 0.77 \\
\hline \multicolumn{5}{|l|}{ 失語 $(\%)^{\mathrm{b}}$} \\
\hline あり & 13.4 & 23.6 & 12.5 & 0.10 \\
\hline \multicolumn{5}{|l|}{ 構音障害 $(\%)^{\mathrm{b}}$} \\
\hline あり & 50.2 & 61.1 & 37.5 & 0.18 \\
\hline \multicolumn{5}{|c|}{ 改訂長谷川式簡易知能評価スケール $(\%)^{\mathrm{b}}$} \\
\hline 20 点以下 & 53.3 & 66.7 & 87.5 & 0.03 \\
\hline 21 点以上 & 46.7 & 33.3 & 12.5 & \\
\hline \multicolumn{5}{|l|}{ Barthel Index $(\%)^{\mathrm{b}}$} \\
\hline $0-20$ 点 & 59.2 & 81.9 & 100.0 & $<0.01$ \\
\hline $21-60$ 点 & 30.7 & 16.7 & 0.0 & \\
\hline $61-100$ 点 & 10.1 & 1.4 & 0.0 & \\
\hline
\end{tabular}

a 一元配置分散分析

${ }^{\mathrm{b}} \chi^{2}$ 検定

${ }^{\mathrm{c}}$ Kruskal-Wallis 検定 
BRS 上肢・手指 I もしくは I の者が約 $35 \%$, 半数以上 の者が感覚障害を有していた。くも膜下出血群は, Barre arm signの認められない者が半数㫟り, 腱反射が 正常の者は約 9 割, 6 割以上の者で感覚は正常であった。 HDS-R が 20 点以下の者は, 脳梗塞群 $53.3 \%$, 脳出血群 $66.7 \%$, くも膜下出血群 $87.5 \%$ であった。 BI が 20 点以 下の者は, くも膜下出血群では全員が該当し, 脳梗塞群 は 59.2\%，脳出血群は $81.9 \%$ であった。

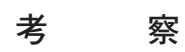

本研究は脳血管疾患患者を対象に, 上肢機能の予後予 測モデル式作成に向けたデータセットを構築するため, 研究デザインと初回調査時に打ける対象者の特性及び急 性期症状について示した。

本研究に扮汀る解析対象者の内訳は，357人のらち脸 梗塞が最も多く $(77.6 \%)$ ，〈も膜下出血は全体の $2.2 \%$ と少なかった。脳梗塞群, 脳出血群, くも膜下出血群の 3 群間に掞いて, 有意な差が認められた要因は, 対象者 の特性では年齢, 損傷部位, 疾患既往歴, 急性期症状で は感覚, 握力, 認知機能, ADL であった。本研究と先 行研究に打ける対象者の急性期症状を比較すると, 本研 究の対象者は片麻痺症状や高次脳機能障害の認められる 者が多かった（6)。これは, 本研究対象者はリハビリテー ションが処方された者であるため, リハビリテーション を必要とする症状を有する者が多く, 脳血管疾患を発症 した全対象者を採用した先行研究よりも上記の症状を示 寸者が多かったことが考光られる。病型別では, 先行研 究の対象者は, くも膜下出血群に打いて, 脳梗塞及び脳 出血群よりも片麻痺症状の認められる者が少ないことが 示された (6)。一方, 脳梗塞よりも脳出血の対象者で, 意 識障害の認められる者が多いことが報告されていた（7）。 本研究結果に扣いても同様の傾向が示されて扣り, 本研 究結果は先行研究の結果を支持するものであった。国内 に扣いて, 脳血管疾患患者を対象に心身機能やADL に おける急性期症状の詳細を調査した研究は少なく $(6,7)$, 急性期症状は上肢機能の予後に大きな影響を及洔すこと から（1-3），今後さらなる調査が必要と考光る。

本研究の限界として以下のことが考觉られる。第一に, 本研究では梗塞や出血の詳細な病変サイズまでは分から なかった。各病型の病変サイズにより重症度は異なるた め $(15,16)$, 病型の久で対象者の急性期症状を比較する には限界があると考觉られる。第二に, 本研究は竹田綜 合病院のみの対象者で調査を行ったため，特性や急性期 症状を一般化するためには，他の施設での調査も必要と 考觉る。第三に, 本研究ではリハビリテーション場面で 用いられている心身機能やADL の評価内容から上肢機 能の予後を予測することを目指しているため，リハビリ テーションが処方された者のみを対象とした。したがっ て, 脳血管疾患を発症した全患者の特性及び急性期症状 を示すことはできなかった。
本研究は研究デザインと初回調査時における対象者の 特性及び急性期症状について病型別に示した。その結果, 平均年齢は病型間で有意差が認められ, 急性期症状では, 感覚や握力といった身体機能に加光, 認知機能, ADL に扔いても病型間での有意差が認められた。今後は，こ のような特性，急性期症状を有する者を対象として，上 肢機能の予後に関連する要因を明らかにし，その要因を 基に予後予測モデル式を作成していく。

\section{謝辞}

本研究はひと・健康・未来研究財団の助成を受け実施 しました。この場を借りて深謝いたします。

利益相反なし

\section{文献}

( 1 ) Coupar F, Pollock A, Rowe P, Weir C, Langhorne P. Predictors of upper limb recovery after stroke: a systematic review and meta-analysis. Clin Rehabil 2012;26:291-313.

(2) Nijland RH, van Wegen EE, Harmeling-van der Wel BC, Kwakkel G; EPOS Investigators. Presence of finger extension and shoulder abduction within 72 hours after stroke predicts functional recovery: early prediction of functional outcome after stroke: the EPOS cohort study. Stroke 2010; 41:745-750.

( 3 ) Smania N, Paolucci S, Tinazzi M, Borghero A, Manganotti P, Fiaschi A, Moretto G, Bovi P, Gambarin M. Active finger extension: a simple movement predicting recovery of arm function in patients with acute stroke. Stroke 2007;38: 1088-1090

( 4 ) Kitamura A, Nakagawa Y, Sato M, Iso H, Sato S, Imano H, Kiyama M, Okada T, Okada H, Iida M, Shimamoto T. Proportions of stroke subtypes among men and women $>$ or $=40$ years of age in an urban Japanese city in 1992, 1997, and 2002. Stroke 2006;37:1374-1378.

（５）喜多義邦。発症登録からみた罹患率の動向．上島弘嗣 (編), NIPPON DATA からみた循環器疾患のエビデン ス. 東京 : 日本医事新報社, 2008, 39-42.

（6）青木志郎, 大梘俊輔, 松本昌泰, 金 大成, 小林祥泰. 病型別にみた初発神経症状の頻度. 小林祥泰 (編), 脳卒中データバンク 2009. 東京: 中山書店, 2009, 32-33.

( 7 ) Sugimoto S, Kanda T, Sakai F. Predicting long-term functional outcome of stroke using multivariate analysis. J Phys Ther Sci 2004;16:129-135.

（8）太田富雄, 和賀志郎, 半田 肇, 斎藤 勇, 竹内一夫, 鈴木二郎, 高久 晃. 意識障害の新しい分類法試案 数量的表現（III群 3 段階方式）の可能性について. 脳 神経外科 1974;2:623-627.

( 9 ) Brunnstrom S. Movement Therapy in Hemiplegia: A Neurophysiological Approach. New York: Harper \& Row, 1970.

（10）加藤伸司，下垣 光，小野寺敦志，植田宏樹，老川賢 
三，池田一彦，小坂敦二，今井幸充，長谷川和夫. 改 定長谷川式簡易知能評価スケール (HDS-R) の作成. 老年精神医学雑誌 1991;2:1339-1347.

(11) Mahoney FI, Barthel D. Functional evaluation: The Barthel Index. Md State Med J 1965;14:56-61.

(12) Bohannon RW, Smith MB. Interrater reliability of a modified Ashworth scale of muscle spasticity. Phys Ther 1987;67:206-207.

（13）中村隆一，森山早苗. リハビリテーションマニュアル 8 脳卒中患者の上肢機能検査（MFT） と機能的作業 療法. 埼玉 : 国立身体障害者リハビリテーションセン ター, 2000 .
（14）三好正堂. 脳卒中・片麻痺からの回復. 岩倉博光，岩 谷 力, 土肥信之 (編), 臨床リハビリテーション脳 卒中 I 脳卒中のみかた. 東京: 医歯薬出版, 1990, 61-64.

(15) Saver JL, Johnston KC, Homer D, Wityk R, Koroshetz W, Truskowski LL, Haley EC. Infarct volume as a surrogate or auxiliary outcome measure in ischemic stroke clinical trials. The RANTTAS Investigators. Stroke 1999;30:293-298.

(16) Yoo AJ, Chaudhry ZA, Nogueira RG, Lev MH, Schaefer PW, Schwamm LH, Hirsch JA, González RG. Infarct volume is a pivotal biomarker after intra-arterial stroke therapy. Stroke 2012;43:1323-1330. 